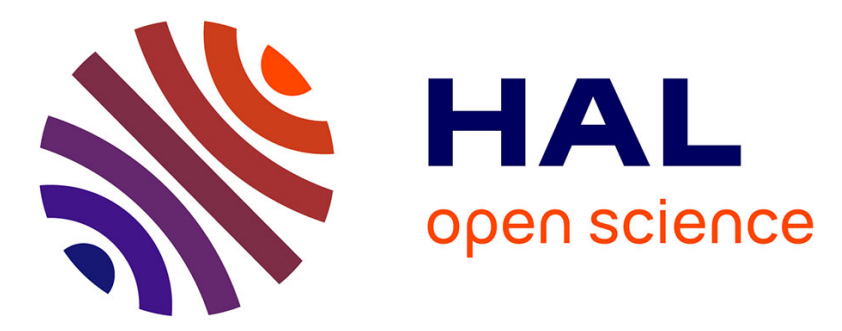

\title{
Photolatent ring-opening metathesis polymerization in miniemulsion: a powerful approach to produce polynorbornene latexes
}

Loïc Pichavant, Patrick Lacroix-Desmazes, Abraham Chemtob, Julien Pinaud, Valérie Héroguez

\section{To cite this version:}

Loïc Pichavant, Patrick Lacroix-Desmazes, Abraham Chemtob, Julien Pinaud, Valérie Héroguez. Photolatent ring-opening metathesis polymerization in miniemulsion: a powerful approach to produce polynorbornene latexes. Polymer Chemistry, 2018, 9 (46), pp.5491-5498. 10.1039/C8PY01011K . hal-01943309

\section{HAL Id: hal-01943309 \\ https://hal.science/hal-01943309}

Submitted on 27 Jan 2020

HAL is a multi-disciplinary open access archive for the deposit and dissemination of scientific research documents, whether they are published or not. The documents may come from teaching and research institutions in France or abroad, or from public or private research centers.
L'archive ouverte pluridisciplinaire $\mathbf{H A L}$, est destinée au dépôt et à la diffusion de documents scientifiques de niveau recherche, publiés ou non, émanant des établissements d'enseignement et de recherche français ou étrangers, des laboratoires publics ou privés. 


\title{
Photolatent Ring-Opening Metathesis Polymerization in Miniemulsion: a Powerful Approach to Produce Polynorbornene Latexes
}

\author{
Loïc Pichavant, ${ }^{a}$ Patrick Lacroix-Desmazes, ${ }^{b}$ Abraham Chemtob, ${ }^{c, d}$ Julien Pinaud, ${ }^{b}$ and Valérie Héroguez, ${ }^{a *}$
}

\begin{abstract}
The use of miniemulsion Ring-Opening Metathesis Polymerization (ROMP) to form polyunsaturated latexes is still a largely unexplored field. The main obstacle remains the preparation of a chemically-stable monomer/catalyst miniemulsion, which is generally jeopardized by the high reactivity of ROMP catalysts at ambient temperature. To overcome this drawback, a photo-latent ROMP catalytic system has been employed for the first time. Our approach starts with a Nheterocyclic carbene (NHC) photogenerating system (1,3-bis(mesityl)imidazolium tetraphenylborate / 2-isopropylthioxanthone) which enables the in situ formation of an active NHC-derived Ru catalyst. The ability to initiate the ROMP in miniemulsion by a photoactive way depends on the absorption conditions of the initial formulation due to irradiation attenuation by scattering. In this contribution, the optimization of an aqueous norbornene miniemulsion in order to improve the irradiation penetration depth is presented in a first part. In a second part, the miniemulsion ROMP is investigated by using the NHC photogenerating system and two ruthenium complex pre-catalysts $\left[\mathrm{RuX}_{2}(\mathrm{p}\right.$-cymene)] dimer $(\mathrm{X}=\mathrm{Cl}$ or I). Stable PNb latexes with particle size in the range of $100 \mathrm{~nm}$ were obtained.
\end{abstract}

a.Laboratoire de Chimie des Polymères Organiques, CNRS UMR5629, IPB-ENSCBP, Université de Bordeaux, Pessac, France. E-mail : heroguez@enscbp.fr

b.ICGM Université de Montpellier, CNRS, ENSCM, Montpellier, France.

c. Université de Haute-Alsace, CNRS, IS2M UMR7361, F-68100 Mulhouse, France.

d. Université de Strasbourg, France.

\section{Introduction}

Aqueous polymer latexes have high industrial interests, firstly, because water is a cheap, safe and environmentally friendly solvent. Secondly, because the aqueous polymer dispersions feature specific properties such as low viscosity and filmforming ability (provided proper adjustment of the $T_{\mathrm{g}}$ of the polymer), which make them relevant for many applications including coatings, adhesives, paper coating, inks, additives for construction materials, and non-woven textiles. ${ }^{1}$ Although there is no commercial application known today, miniemulsion free radical polymerization is a powerful way to obtain polymer latexes thanks to the tolerance of free radicals towards water. $2,3,4,5$ In addition, miniemulsion polymerization relies on droplet nucleation allowing the polymerization of very hydrophobic monomers as well as the preparation of organic/inorganic nanocomposites, which are difficult to achieve with conventional ab initio emulsion polymerization. In a typical miniemulsion route, a mixture containing the monomer(s), a water-insoluble initiator, and a costabilizer (to avoid Ostwald ripening) forms an organic phase. This latter is then mixed with the aqueous phase containing a surfactant before being emulsified by high energy input usually through an ultrasonifier. Miniemulsion droplets typically display average diameters ranging from 40 to $400 \mathrm{~nm}$, and are kinetically stable. Polymerization is generally triggered upon heating when using thermal radical initiators. Contrary to radical polymerization, only few contributions have been reported regarding the formation of latexes by Ring-Opening Metathesis Polymerization (ROMP) in aqueous dispersed media. The challenges of such route are firstly the water sensitivity of most ROMP catalysts, and secondly, their non-latent character. Therefore, the active catalyst jeopardizes the preparation of a chemically-stable monomer miniemulsion, causing premature polymerization.

ROMP in miniemulsion was introduced by Claverie et al. ${ }^{6}$ in 2001. To circumvent the issue of premature polymerization, they first prepared a miniemulsion containing a hydrophobic catalyst ( $1^{\text {st }}$ generation Grubbs' catalyst dissolved in a small amount of toluene) and added dropwise the cycloolefin monomer. Nevertheless, only the least reactive monomers (cyclooctene and cyclooctadiene) could be used without miniemulsion destabilization. In previous contributions, we reported the miniemulsion ROMP of norbornene $(\mathrm{Nb})$ by the addition of well-defined poly(ethylene oxide)-based ruthenium carbene as water-soluble macroinitiators to monomer miniemulsion. ${ }^{7}$ Stable polynorbornene (PNb) latex particles with average diameter of $200-500 \mathrm{~nm}$ were obtained with almost quantitative monomer conversion. Following a similar strategy, a tandem ROMP and Atom Transfer Radical Polymerization (ATRP) in miniemulsion was also investigated. ${ }^{8,9}$ However, the issue was the cumbersome and tricky synthesis of the macroinitiator. At the same time, miniemulsion ROMP of an amphiphilic PEO-based cyclobutene macromonomer was reported by Le et al. ${ }^{10}$ using Grubbs' third generation catalyst. The initial miniemulsion was stable and no coagulation appeared, but the system led to partial macromonomer conversion after $48 \mathrm{~h}$ of reaction at room temperature.

In this context, we envision that a major improvement for miniemulsion ROMP could be made by incorporating a hydrophobic latent catalytic system into the organic droplet 
phase. Several pathways are described in the literature to generate latent ROMP catalytic systems using chemical, ${ }^{11,12}$ thermal ${ }^{13}$ or mechanochemical means (ultrasound), ${ }^{14}$ but the convenient method would be the use of an irradiation stimulus $^{15-17}$ In most examples in solution, photolatent systems consist in ruthenium complexes made inactive by chelating ligands or electron-rich carbene moieties. ${ }^{18}$ Conversion into an active form proceeds by photoinduced ligand dissociation/rearrangement ${ }^{19}$ or isomerisation reactions. ${ }^{20-24}$ In contrast, we recently proposed a completely different approach based on two consecutive steps: the photogeneration of $\mathrm{N}$ heterocyclic carbene (NHC) ligand, and its subsequent reaction with an inactive Ru precatalyst to form in situ an active NHCderived Ru ROMP catalyst. ${ }^{25}$ The combination of 1,3dimesitylimidazolium tetraphenylborate salt $\left(\mathrm{IMesH}^{+} \mathrm{BPh}_{4}^{-}\right)$ (NHC protected form) with 2-isopropylthioxanthone (ITX) (sensitizer) proved to be able to generate the 1,3dimesitylimidazol-2-ylidene (IMes) NHC upon UV irradiation $(365 \mathrm{~nm}){ }^{26}$ In regard to the second step, $\left[\mathrm{RuCl}_{2}\right.$ (p-cymene)] dimer $^{27}$ as the inactive precatalyst, formed in situ the active $\mathrm{RuCl}_{2}$ (p-cymene)(IMes) Noels' catalyst ${ }^{28}$ in presence of IMes to initiate the ROMP of $\mathrm{Nb}$.

We show herein that such tricomponent catalytic system [RuCl 2 (p-cymene)] dimer/IMesH ${ }^{+} \mathrm{BPh}_{4}-/ \mathrm{ITX}$ can also serve for photoROMP in miniemulsion. To the best of our knowledge, no photolatent system for ROMP of cycloolefin in aqueous dispersed media has been reported yet. In a first part of this study, particular attention has been paid to miniemulsion formulation in order to optimize incident irradiation, and increase the uniformity of irradiation distribution within the reactor. Indeed, a photochemical reaction is only possible in irradiated volumes. In a heterogeneous or dispersed medium, the incident photon flux is attenuated because of light absorption and scattering. ${ }^{29}$ To mitigate the detrimental effect of scattering on photopolymerization in dispersed system, $\mathrm{Nb}$ miniemulsions with an average droplet smaller than $100 \mathrm{~nm}$ have been prepared and their optical properties (extinction) have been evaluated by UV/Vis Spectroscopy, based on measurements in regular transmission. Finally, photo-induced ROMP of $\mathrm{Nb}$ has been triggered through the water-insoluble tricomponent catalytic system dissolved in the monomer droplets, and the results have been compared with photoROMP in solution.

\section{Experimental section}

\section{Materials}

Ethanol (EtOH; 96\%), chloroform $\quad\left(\mathrm{CHCl}_{3} ; \quad 99.4 \%\right)$, dichloromethane (DCM; 99.8\%) from VWR Chemicals and 1,2dichloroethane (DCE; 99.8\%) from Aldrich were used without further purifications. 1,3-bis(mesityl)imidazolium chloride $\left(\mathrm{IMesH}^{+} \mathrm{Cl}-; 97 \%\right)$ and sodium tetraphenylborate $\left(\mathrm{NaBPh}_{4}\right.$; 99.5\%) were purchased from $A B C R$. Dichloro(pcymene)ruthenium(II) dimer ([RuCl $\left.2(\mathrm{pCy})]_{2} ; 98 \%\right)$ and diiodo(pcymene)ruthenium(II) dimer $\left(\left[\mathrm{RuI}_{2}(\mathrm{pCy})\right]_{2}\right)$ were purchased from Alfa Aesar. 2-isopropylthioxanthone (ITX; 98\%) was obtained from $\mathrm{TCl}$ Europe. CREMOPHOR CO40 and CREMOPHOR RH60 (steric surfactants) were obtained from
BASF. Merpol ${ }^{\circledR} \mathrm{HCS}$, Tween $^{\circledR} 20$, Brij $^{\circledR}$ S100 (steric surfactants), norbornene $(\mathrm{Nb})$ and hexadecane were purchased from Aldrich. The structure of the steric surfactants is described in the results and discussion part. Deionized water was obtained with a Millipore Milli-Q Biocel A10 purification unit.

\section{Irradiation source}

UV irradiation was performed with a LIGHTNINGCURE ${ }^{\circledR}$ Series apparatus from HAMAMATSU equipped with a light guide, a medium pressure mercury-xenon lamp and a filter at $365 \mathrm{~nm}$. Samples were placed at $10 \mathrm{~cm}$ of the light guide. Irradiance was measured with a Power Puck II radiometer from EIT ${ }^{\circledR}$ (20 $\mathrm{mW} / \mathrm{cm}^{2}$ at $365 \mathrm{~nm}$ ).

\section{Characterization methods}

${ }^{1} \mathrm{H}$ NMR studies were acquired using a Bruker spectrometer 400 $\mathrm{MHz}$ employing $\mathrm{CDCl}_{3}$ or DMSO-d6 as solvent at $25^{\circ} \mathrm{C}$. Conversions of $\mathrm{Nb}$ were determined by gas chromatography (GC) with hexadecane as internal standard, using a VARIAN GC3900 (apolar capillary column BP1-30m; injector temperature: $250^{\circ} \mathrm{C}$; detector temperature: $300^{\circ} \mathrm{C}$; ramp temperature: $2 \mathrm{~min}$ at $50^{\circ} \mathrm{C}+10^{\circ} \mathrm{C} / \mathrm{min}$ until $250^{\circ} \mathrm{C} ; \mathrm{GC}$ retention times: $\mathrm{t}^{\mathrm{GC}}{ }_{\mathrm{Nb}}=1.77 \mathrm{~min} ; \mathrm{t}^{\mathrm{GC}}$ dodecane $\left.=13.25 \mathrm{~min}\right)$. $\mathrm{UV} / \mathrm{Vis}$ measurements were performed with a UV/Vis spectrometer Agilent Carry 4000 (optical path length: $1 \mathrm{~mm}$ ). Dynamic light scattering (DLS) measurements were performed using a MALVERN Zetasizer Nano ZS equipped with He-Ne laser ( $4 \mathrm{~mW}$; $633 \mathrm{~nm}$ ). All spectra are the average of three measurements. Before measurements, latexes were diluted about 250 times to minimize multiple scatterings caused by high concentration. The scattering angle used was $90^{\circ}$. Size-exclusion chromatography (SEC) was performed in tetrahydrofuran (THF) (1 $\mathrm{mL} \mathrm{min}^{-1}$ ) with trichlorobenzene as the flow marker, using both refractometric and UV detectors. TEM pictures were performed with a HITACHI H7650 microscope operating at an accelerating voltage of $80 \mathrm{kV}$. Latexes were diluted 70 times and $10 \mu \mathrm{L}$ of the final latexes were poured on carbon-carbon grids and dried in normal atmosphere. The pictures were recorded with Digital Micrograph (GATAN) and analyzed with the software ImageJ to determine the particle average diameter and the polydispersity (PDI). PDI is calculated with the following formula (Equation 1):

$P D I=\left(\frac{\sigma}{D}\right)^{2} \quad$ Equation 1

With:

$D:$ the average diameter

$\sigma:$ the standard deviation

\section{Synthesis of 1,3-dimesitylimidazolium tetraphenylborate $\left(\mathrm{IMesH}^{+} \mathrm{BPh}_{4}^{-}\right)^{30}$}

In a typical experiment, $2.28 \mathrm{~g}$ of $\mathrm{IMesH}^{+} \mathrm{Cl}^{-}\left(341 \mathrm{~g} / \mathrm{mol} ; 6.710^{-3}\right.$ $\mathrm{mol}$ ) are dissolved in $67.5 \mathrm{~mL}$ of degassed ethanol (FreezePump-Thaw method). A solution of $\mathrm{NaBPh}_{4}(3.59 \mathrm{~g} ; 342 \mathrm{~g} / \mathrm{mol}$; $\left.10.510^{-3} \mathrm{~mol}\right)$ in degassed ethanol $(67.5 \mathrm{~mL})$ is added dropwise under a nitrogen flux. The formed precipitate $\left(\mathrm{IMesH}^{+} \mathrm{BPh}_{4}{ }^{-}\right)$is filtrated, washed with water and ethanol and dried overnight 


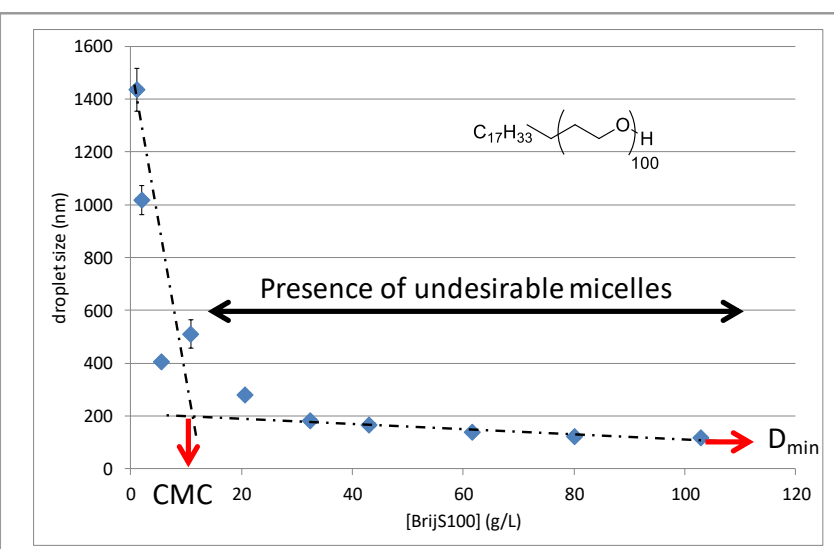

Figure 1: Droplet size as a function of the Brij ${ }^{\oplus} \mathrm{S} 100$ concentration

under vacuum. Mass Yield: $85 \%-{ }^{1} \mathrm{H}$ NMR data in DMSO-d6: $\delta$ (ppm) $(400 \mathrm{MHz}): 2.12(\mathrm{~s} ; 12 \mathrm{H}) ; 2.36(\mathrm{~s} ; 6 \mathrm{H}) ; 6.79(\mathrm{t} ; 4 \mathrm{H}) ; 6.94$ $(\mathrm{m} ; 8 \mathrm{H}) ; 7.21(\mathrm{~m} ; 12 \mathrm{H}) ; 8.26(\mathrm{~s} ; 2 \mathrm{H}) ; 9.64(\mathrm{~s} ; 1 \mathrm{H})$. (Supplementary information, Figure $\mathrm{S} 1$ )

\section{Miniemulsion formation}

Aqueous phase was prepared by adding a variable amount (0.01-1 g) of surfactant (CREMOPHOR CO40, CREMOPHOR RH60, Merpol ${ }^{\circledR}$ HCS, Tween ${ }^{\circledR} 20$ or Brij ${ }^{\circledR}$ S100) to $10 \mathrm{~mL}$ of milliQ water. The organic phase was prepared by mixing $\mathrm{Nb}$ ( $25 \mathrm{w}-\%)$ with hexadecane $(10 \mathrm{w}-\%)$ in the solvent (DCM or DCE) (65 w$\%)$. Then, the organic phase $(0.5,1$ or $2 \mathrm{~g}$ for miniemulsions at 5,10 or $20 \mathrm{w} / \mathrm{w}-\%$ of dispersed phase versus the continuous phase respectively) was added to the aqueous phase and the pre-miniemulsion was stirred during 1 hour. Then a miniemulsion was formed by ultrasonication with a BioBlock Vibra-Cell 75043 (750 W) equipped with an ultrasonic tip (from $2 \mathrm{~min}$ to $20 \mathrm{~min}$; pulse mode, $5.0 \mathrm{~s}$ on $5.0 \mathrm{~s}$ off). During ultrasonication, samples were placed in an ice bath to avoid any temperature increase.

\section{Polymerization in solution}

A solution of $\mathrm{Nb}$ ( $25 \mathrm{w}-\%$; $823 \mathrm{mg} ; 8.7510^{-3} \mathrm{~mol} ; 510$ eq.) and hexadecane (10 w-\%; $329 \mathrm{mg} ; 427 \mu \mathrm{L}$ ) in dichloroethane $(2.47$ $\mathrm{mL} ; 2 \mathrm{~mL}$ ) was prepared and degassed (Freeze-Pump-Thaw method). Then, $\left[\mathrm{RuCl}_{2}(\mathrm{p}-\mathrm{Cy})\right]_{2}$ (1 eq.; $1.7110^{-5} \mathrm{~mol} ; 10 \mathrm{mg}$ ) or $\left[\mathrm{RuI}_{2} \text { (p-Cy) }\right]_{2}$ (1eq.; $1.7110^{-5} \mathrm{~mol} ; 17 \mathrm{mg}$ ) and $\mathrm{IMesH}^{+} \mathrm{BPh}_{4}^{-}(5$ eq.; $8.610^{-5} \mathrm{~mol} ; 54 \mathrm{mg}$ )/ITX (2.5 eq.; $4.310^{-5} \mathrm{~mol} ; 11 \mathrm{mg}$ ) were added under inert atmosphere (glovebox). This solution was then transferred inside a quartz cuvette (optical path length: 1 $\mathrm{mm}$ ) and irradiated during different times. After irradiation, the samples were dissolved in a minimum of dichloromethane and analyzed by gas chromatography ( $\mathrm{Nb}$ conversion). Finally, the samples were precipitated in acetone, filtrated, dried under vacuum and the obtained polymers were analyzed by ${ }^{1} \mathrm{H}$ NMR and SEC (data are given in the Results and discussion part, Figure S3 and Figure S5).

\section{Polymerization in miniemulsion}

$10 \mathrm{~mL}$ of a solution of Brij ${ }^{\circledR} \mathrm{S} 100$ in millQ water $(100 \mathrm{~g} / \mathrm{L})$ were degassed by bubbling nitrogen during 1 hour. Then, $0.5,1$ or 2 $\mathrm{g}$ (for miniemulsions at 5,10 or $20 \mathrm{w} / \mathrm{w}-\%$ respectively) of degassed organic phase containing the catalytic system were added under nitrogen (preparation of the organic solution are described in the previous section "polymerization in solution "). The pre-miniemulsion was stirred during 1 hour. Then, the miniemulsion was formed by ultrasonication during $2 \mathrm{~min}$ (pulse mode, $5.0 \mathrm{~s}$ on $5.0 \mathrm{~s}$ off). The miniemulsion was then transferred inside a quartz cuvette (optical path length: $1 \mathrm{~mm}$ ) and irradiated during different times. After irradiation, the samples were dissolved in a minimum of THF and analyzed by gas chromatography ( $\mathrm{Nb}$ conversion). Finally, the samples were precipitated in acetone, filtrated, dried under vacuum and the obtained polymers were analyzed by ${ }^{1} \mathrm{H}$ NMR and SEC (data are given in the Results and discussion part Figure S4 and Figure S6).

\section{Results and discussion}

In a first stage of this study, attention has been paid to optimize the formulation of the miniemulsion to obtain droplets sizes lower than $100 \mathrm{~nm}$ (to minimize radiation scattering). For the sake of simplicity, this part of the study was performed without ROMP initiator.

\section{Formulation of the $\mathrm{Nb}$ miniemulsion}

The aqueous miniemulsion is composed of a continuous phase - water and surfactant - and a dispersed phase - organic solvent, monomer $(\mathrm{Nb})$ and hexadecane used as costabilizer to prevent Ostwald ripening. The miniemulsion is formed by first stirring the two-phases (pre-emulsion) and second by ultrasonication. Several parameters have been screened in order to optimize the formulation.

Influence of the type of surfactant: In this part, the dispersed phase concentration was $10 \mathrm{w} / \mathrm{w}-\%$ and was composed of $\mathrm{Nb}$ ( $80 \mathrm{w}-\%$ ) and hexadecane (20 w-\%).

The type of surfactant must be chosen with care. Indeed, we have shown that convensional ionic surfactants such as SDS can interact with $\mathrm{IMesH}^{+} \mathrm{BPh}_{4}^{-}$by counterion exchange having a negative effect on the initiator formation (Figure S2, supplementary information). This kind of reaction is well known in ionic liquid synthesis. ${ }^{31}$ Consequently, nonionic surfactants were employed. A series of five polymeric surfactants has been selected as a function of their hydrophilic/lipophilic balance (HLB); a high HLB being required to stabilize an oil-in-water emulsion. The miniemulsion was formed by ultrasonication during 10 minutes at $50 \%$ of the maximal power. For each surfactant, the droplet size determined by DLS has been plotted as a function of the surfactant concentration. From these curves can be extracted two fundamental parameters: the critical micelle concentration (CMC), from this concentration the droplet stabilization is optimal and the addition of more stabilizer would induce the undesirable formation of micelles in the continue phase in the presence of the organic dispersed 
phase and the minimal diameter of the droplets $\left(D_{\min }\right)$ (Figure 1).

The results for the five tested surfactants are summarized in the Table 1. The smallest droplets were obtained with the $\mathrm{Brij}^{\circledR} \mathrm{S} 100$ and the CREMOPHOR CO40 with a concentration of $100 \mathrm{~g} / \mathrm{L}$ $\left(D_{\min }\right.$ around $\left.\left.120 \mathrm{~nm}\right)\right)$. As the $B$ rij ${ }^{\circledR} \mathrm{S} 100$ is a more common and cheaper surfactant, it has been chosen for the rest of the study.

Influence of the type and amount of solvent in the dispersed phase: For these experiments, $\mathrm{Brij}^{\circledR} \mathrm{S} 100$ was used as surfactant and the organic phase was composed of the solvent (65 w-\%; minimal concentration for which the catalytic systems is still soluble), $\mathrm{Nb}(25 \mathrm{w}-\%)$ and hexadecane (10 w-\%). For the preparation of the organic phase, the two main parameters were studied: the nature of the solvent (DCM or DCE), and its weight content $(5,10$ or $20 \mathrm{w} / \mathrm{w}-\%)$. The results are presented in Table 2.

Regarding the nature of the solvent (entries (1) and (5) and entries (3) and (6)) the use of DCE leads to smaller droplets. The organic phase content has also an influence on droplet size (entries (5), (7) and (8)). As expected, the less the organic phase ratio is, the smaller the droplets are ${ }^{3}$. With a dispersed phase at $5 \mathrm{w} / \mathrm{w}-\%$, very small droplets are obtained (36 nm; entry (7)).

Ultrasonication parameters optimization: The last studied parameters for the optimization of the miniemulsion were the ultrasonication conditions such as the ultrasonication time and the power of the ultrasonication probe (Table 2). Regarding the first parameter (entries (1), (3) and (4) and entries (5) and (6)), an increase of the droplet size was observed with the ultrasonication time. The same behavior was observed with the increase of the sonication power (entries (1) and (2)). This phenomenon is very surprising because droplet size usually decreases with these parameters essentially due to the greater efficiency of the emulsification step but sometime partially due to an increase of the temperature which involves a partial evaporation of the organic phase homogenization. ${ }^{3}$ In our case, this increase in size of the droplets could be explained by the partial precipitation of the surfactant with the increase of the medium temperature particularly marked beyond $60 \%$

Table 1: Characteristics of the tested steric surfactants.

\begin{tabular}{|c|c|c|c|c|}
\hline Surfactant & $\begin{array}{l}\text { Description } \\
\text { /formula }\end{array}$ & HLB & $\begin{array}{c}\text { CMC } \\
\text { (g/L) } \\
\text { (DLS) }\end{array}$ & $\begin{array}{l}D_{\min } \\
(n m) \\
(D L S)\end{array}$ \\
\hline $\begin{array}{l}\text { CREMOPHOR } \\
\text { CO40 }\end{array}$ & $\begin{array}{l}\text { PEG-hydroxylated } \\
\text { castor oil }\end{array}$ & - & $7-8$ & 118 \\
\hline $\begin{array}{c}\text { CREMOPHOR } \\
\text { RH60 }\end{array}$ & $\begin{array}{l}\text { PEG-hydroxylated } \\
\text { castor oil }\end{array}$ & - & 5 & 190 \\
\hline Merpol ${ }^{\circledR} \mathrm{HCS}$ & Oleyl-PEG & 15 & $12-13$ & 190 \\
\hline Tween $^{\circledR} 20$ & & 16 & 5 & 170 \\
\hline $\mathrm{Brij}^{\circledR} \mathrm{S} 100$ & (1) & 18 & 10 & 119 \\
\hline
\end{tabular}

ultrasonication power. ${ }^{32}$ Indeed, even if an ice bath is used during the sonication step to avoid the temperature increase it is not possible to prevent it completely and the reactor is a little bit hot after the homogenization step. Final temperature can locally reach $70^{\circ} \mathrm{C}$. Supplementary experiments, consisting in placing a miniemulsion of $83 \mathrm{~nm}$ droplets (entry (1), Table 2) diameter in a hot water-bath during one hour confirmed the increase of the droplet size with the temperature (final droplet size $D=104 \mathrm{~nm}$ ). By contrast, no destabilization occurred within 24 hours at room temperature for the same miniemulsion, which confirmed the miniemulsion stability during the polymerizations. Because miniemulsions prepared using DCE as solvent and 2 min ultrasonication at a power of $50 \%$ (entries (5), (7) and (8), Table 2) displayed the smallest droplets sizes, this system was selected for the rest of the study.

\section{Evaluation of the miniemulsion optical properties}

In $\mathrm{IMesH}^{+} \mathrm{BPh}_{4}-/ \mathrm{ITX} 2$-component $\mathrm{NHC}$ generating system, the primary photochemical step is electron transfer sensitized by excited triplet ITX. To match with ITX absorption in the UV-A range and avoid $\mathrm{IMesH}^{+} \mathrm{BPh}_{4}$ - absorption, a medium pressure $\mathrm{Hg}$ lamp equipped with a filter at $365 \mathrm{~nm}$ has been used. In order to assess the level of extinction (due to the combined effect of scattering and absorption of ITX), the miniemulsions were analyzed by spectrophotometric methods based on measurements in regular transmission at $365 \mathrm{~nm}$. Measurements were performed on three miniemulsions with variable organic phase content: 5,10 and $20 \mathrm{w} / \mathrm{w}-\%$ contained in a $1 \mathrm{~mm}$ thick cell (Table 2 entry (5), (7) and (8)) (Figure 2). UVvisible analysis was also carried out on the organic phase before its emulsification as a reference (blue curve, Figure 2). By following the definition of the absorbance (Equation 2), the percentage of transmitted irradiation can be determined to evaluate the extent of scattering.

$$
A=\log \left(\frac{I}{I_{0}}\right) \quad \text { Equation } 2
$$

With:

- A: the measured absorbance

- I: the transmitted intensity

- Io: the initial intensity

As observed on the Figure 2, in the non-absorbing region (300$800 \mathrm{~nm}$ ), the decrease in organic phase content is manifested by a dramatic increase of the miniemulsion transparency arising from a diminished scattering coefficient. Below $300 \mathrm{~nm}$, monomer absorption domain is very large, involving an important fall of the transparency regardless of the droplet size and consequently of the scattering. At $20 \mathrm{w} / \mathrm{w}-\%$ in droplet phase $(D=103 \mathrm{~nm})$, the transmittance is very low $\left(I_{t} / I_{0}=0.3 \%\right)$. At $10 \mathrm{w} / \mathrm{w}-\%$, the miniemulsion is slightly transparent but only $8 \%$ of the light is transmitted. The best conditions for a highly penetrative miniemulsion is $5 \mathrm{w} / \mathrm{w}-\%\left(D=36 \mathrm{~nm} ; \mathrm{l} / \mathrm{I}_{0}=57 \%\right)$. 
Table 2: Droplets size as a function of the dispersed phase composition and of the sonication parameters.

\begin{tabular}{cccccc}
\hline Entry & Solvent & $\begin{array}{c}\text { Dispersed phase } \\
\text { ratio } \\
(\mathrm{w}-\%)\end{array}$ & $\begin{array}{c}\text { Ultrasonication } \\
\text { time } \\
(\mathrm{min})\end{array}$ & $\begin{array}{c}\text { Ultrasonication } \\
\text { power } \\
(\%)\end{array}$ & $\begin{array}{c}\text { Droplet size }(\mathrm{nm}) \\
(\text { PDI })\end{array}$ \\
\hline$(1)$ & DCM & 10 & 2 & 50 & $83(0.291)$ \\
$(2)$ & 10 & 2 & 70 & $168(0.205)$ \\
$(3)$ & DCM & 10 & 10 & 50 & $174(0.187)$ \\
$(4)$ & DCM & 10 & 20 & 50 & $183(0.181)$ \\
$(5)$ & DCM & 10 & 10 & 50 & $64(0.228)$ \\
$(6)$ & DCE & 10 & 2 & 50 & $162(0.264)$ \\
(7) & DCE & 5 & 2 & 50 & $36(0.264)$ \\
(8) & DCE & DCE & 20 & & $0.290)$ \\
\hline
\end{tabular}

\section{Polymerization tests}

The formulation study for the formation of the miniemulsion was performed with droplets containing only $\mathrm{Nb}$, solvent and hexadecane. The tricomponent catalytic system $\left[\mathrm{RuCl}_{2}(\mathrm{p}-\right.$ cymene)] dimer/IMesH ${ }^{+} \mathrm{BPh}_{4}{ }^{-} / \mathrm{ITX}$ needs to be added in the organic phase for the photoROMP. As previously reported, this catalytic system is very effective for the photoROMP of $\mathrm{Nb}$ in solution using DCM as solvent, allowing to reach full conversion in less than 5 min. ${ }^{33}$ Nevertheless, because DCE was selected as solvent for the organic phase of the miniemulsion, we decided to study the behavior of the catalytic system in this solvent. In addition, the ruthenium dimer pre-catalyst $\left[\mathrm{RuI}_{2}(\mathrm{pCy})\right]_{2}$, instead of $\left[\mathrm{RuCl}_{2}(\mathrm{pCy})\right]_{2}$, was also evaluated for the photoROMP of $\mathrm{Nb}$ (Scheme 1).

System IMesH ${ }^{+} \mathrm{BPh}_{4}-/ \mathrm{ITX} /\left[\mathrm{RuCl}_{2}(\mathrm{pCy})\right]_{2}$ : First, polymerization tests were carried out with $\mathrm{IMes}^{+} \mathrm{BPh}_{4}{ }^{-} / \mathrm{ITX}$ (5 eq./2.5 eq.) in presence of $\left[\mathrm{RuCl}_{2}(\mathrm{pCy})\right]_{2}$ (1 eq.) as pre-catalyst in solution and in miniemulsion with different dispersed phase contents $(5,10$ and $20 \mathrm{w} / \mathrm{w}-\%)$. For this study, the formulations were irradiated at $365 \mathrm{~nm}\left(20 \mathrm{~mW} / \mathrm{cm}^{2}\right)$ during $30 \mathrm{~min}$. $\mathrm{Nb}$ conversions as a function of irradiation times were plotted in Figure 3 while values of molecular weights were reported in Table 3.

In solution, using DCE as solvent, $\mathrm{Nb}$ conversion reached $90 \%$ after 20 min irradiation. Experimental average molar masses were 10 times higher than the theoretical ones, indicating a poor initiation efficiency of the polymerization (Table 3 ).

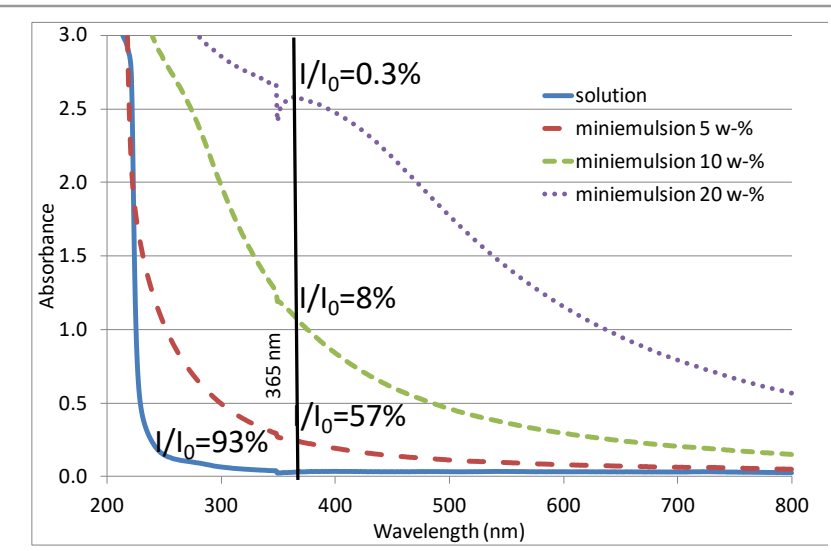

Figure 2: UV-visible analysis of the organic phase (DCE $65 \mathrm{w}-\%, \mathrm{Nb} 25 \mathrm{w}-\%$, hexadecane $10 \mathrm{w}-\%)$ and of the miniemulsions at 5, 10 and $20 \mathrm{w}-\%$. Ultrasonication: $2 \mathrm{~min}$ at $50 \%$; optical path length: $1 \mathrm{~mm}$.
Moreover, the polymer obtained exhibit broad molecular weight dispersity decreasing with the conversion, which is characteristic of an initiation rate much lower than that of propagation. The ${ }^{1} \mathrm{H}$ NMR spectrum of the obtained polymer showed the characteristic signals of $\mathrm{PNb}$, with in particular, the presence of the signal corresponding to the unsaturations of the $\mathrm{PNb}$ chains with the suitable integrations. The cis/trans ratios of the obtained polymers were about 50/50. (Figure S3, supplementary information).

A control experiment was also carried out with $\left[\mathrm{RuCl}_{2}(\mathrm{pCy})\right]_{2}$ alone (without $\mathrm{IMesH}^{+} \mathrm{BPh}_{4}-/ \mathrm{ITX}$ ), without the $\mathrm{NHC}$ precursor (Figure S7, blue curve). Indeed, this precatalyst has proved to be active for the ROMP of Norbornene in DCM under UV irradiation at $365 \mathrm{~nm}$ in the presence of ITX. ${ }^{27}$ In DCE, it appears that $\left[\mathrm{RuCl}_{2}(\mathrm{pCy})\right]_{2}$ alone, is able to polymerize $\mathrm{Nb}$ ( $\mathrm{Nb}$ conversion is higher than $40 \%$ after 30 minutes of irradiation). Thus, during the $\mathrm{Nb}$ ROMP initiated with $\mathrm{IMesH}^{+} \mathrm{BPh}_{4}^{-}$ $/ \mathrm{ITX} /\left[\mathrm{RuCl}_{2}(\mathrm{pCy})\right]_{2}$, a secondary $\mathrm{ROMP}$ initiated by $\left[\mathrm{RuCl}_{2}(\mathrm{pCy})\right]_{2}$ alone occurs. However, it is much less active than with the IMesH $\mathrm{H}^{+} \mathrm{BPh}_{4}-$ /ITX system: $70 \%$ monomer conversion is reached after $5 \mathrm{~min}$ irradiation with $\mathrm{IMesH}^{+} \mathrm{BPh}_{4}-/ \mathrm{ITX} /\left[\mathrm{RuCl}_{2}(\mathrm{pCy})\right]_{2}$ versus $10 \%$ at the same time with $\left[\mathrm{RuCl}_{2}(\mathrm{pCy})\right]_{2}$ alone.

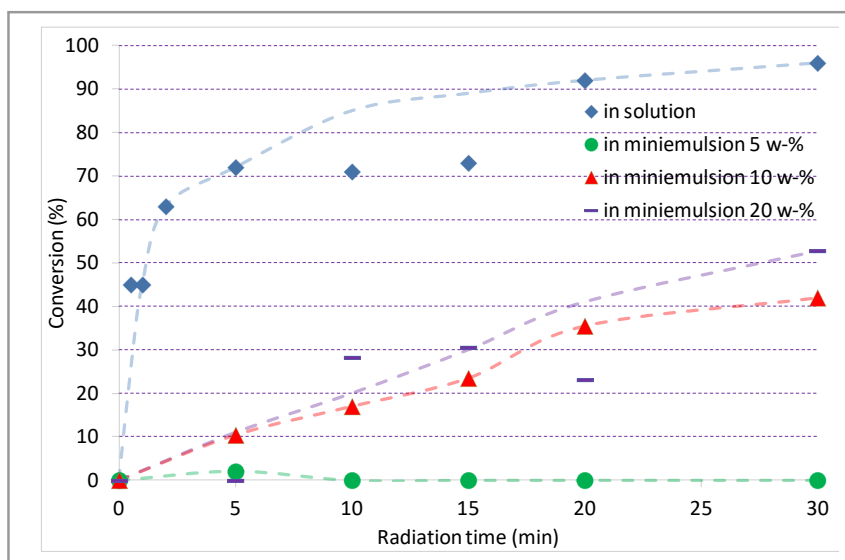

Figure 3: $\mathrm{Nb}$ conversion as a function of the irradiation time with the catalytic system IMes ${ }^{+} \mathrm{BPh}_{4}-/ \mathrm{ITX} /\left[\mathrm{RuCl}_{2}(\mathrm{pCy})\right]_{2}$ in solution (blue curve) and in miniemulsion at $5 \mathrm{w}-\%$ (green curve) at $10 \mathrm{w}-\%$ (red curve) and at $20 \mathrm{w}-\%$ (purple curve). 


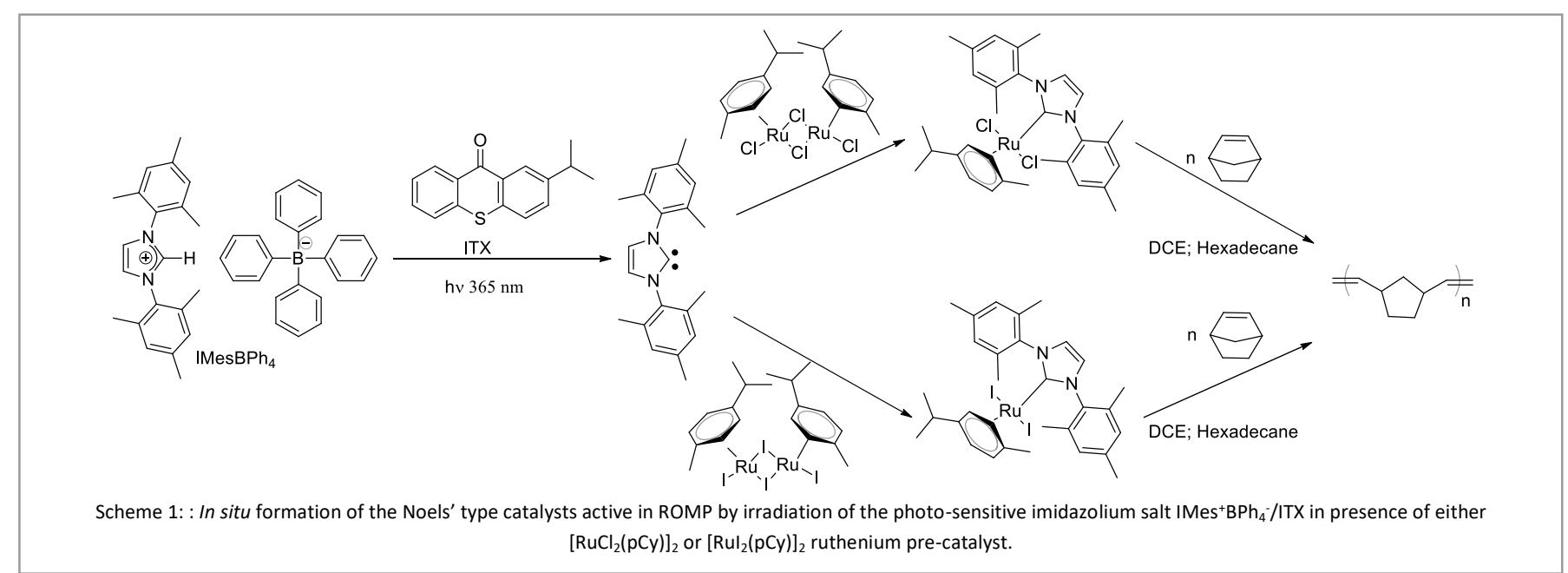

Miniemulsion polymerization was first carried out with a $5 \mathrm{w} / \mathrm{w}-$ $\%$ organic phase content (Figure 3, green curve). Unfortunately, no conversion was observed although this miniemulsion exhibited the best penetration depth. The organic dispersed phase was probably too diluted and the droplets size too small to be activated by irradiation. By contrast, at $10 \mathrm{w} / \mathrm{w}-\%$ (Figure 3 , red curve), conversion reached $40 \%$ after 30 minutes of irradiation (versus $90 \%$ in solution). The characteristic signals of $\mathrm{PNb}$ were observed by ${ }^{1} \mathrm{H}$ NMR spectroscopy (cis/trans ratio also around 50/50) (Figure S4, supplementary information). As in solution ROMP, both ROMP initiated by the formed Noels' catalyst after irradiation and by $\left[\mathrm{RuCl}_{2}(\mathrm{pCy})\right]_{2}$ alone take place (Figure S7, red curve). Experimental average molar masses are also much higher than the theoretical ones and after 20 minutes of irradiation, they became so high that the PNb could not be solubilized in THF for SEC analysis (Table 3). The absence of correlation between the molar masses and the irradiation time probably comes from the difficulty of solubilizing PNb chains of high molar masses and the uncontrolled polymerization initiation. The DLS measurements showed that the particle size after polymerization was very close to the initial droplet size, attesting the good colloidal stability of the miniemulsion upon polymerization (Table 3; Figure 4). In addition, TEM pictures (Figure 4) analyses showed spherical particles with sizes consistent with the sizes measured by DLS ( $D=103 \mathrm{~nm}(0.14)$ for TEM and $\mathrm{D}=105 \mathrm{~nm}$ (0.23) for DLS).

Finally, the polymerization of the miniemulsion at $20 \mathrm{w} / \mathrm{w}-\%$ of dispersed phase was performed in order to check if an increase of the droplet concentration could further improve the initiation process and thus $\mathrm{Nb}$ conversion (Figure 3, purple curve). Nevertheless, no significant improvement was observed. Indeed, the miniemulsion ROMP at $20 \mathrm{w} / \mathrm{w}-\%$ exhibits almost the same conversion profile as the miniemulsion at $10 \mathrm{w} / \mathrm{w}-\%$. This phenomenon can be explained by the fact that the increase of nucleation sites (droplets nucleation) is counterbalanced by a decrease of the transparency (initial droplet size: $\mathrm{D}=143 \mathrm{~nm}(0.240)$ involving a very low miniemulsion transparency). The final particle size ( $D=147 \mathrm{~nm}$ (0.202)) close to the initial droplet size, proved the good stability of the emulsion.

Table 3: Characteristics of the obtained polymers with the catalytic system IMes ${ }^{+} \mathrm{BPh}_{4}{ }^{-} / \mathrm{ITX} /\left[\mathrm{RuCl}_{2}(\mathrm{pCy})\right]_{2}(5 / 2.5 / 1$ equiv.) and particle sizes for the polymerization in miniemulsion at $10 \mathrm{w}-\%$

\begin{tabular}{|c|c|c|c|c|c|c|c|c|c|c|}
\hline & $\begin{array}{l}\text { Irradiation } \\
\text { time (min) }\end{array}$ & 0 & 0.5 & 1 & 2 & 5 & 10 & 15 & 20 & 30 \\
\hline \multirow{3}{*}{$\begin{array}{l}\text { Polymerization in } \\
\text { solution }\end{array}$} & $\begin{array}{c}\mathrm{M}_{\mathrm{n} ; \mathrm{th}} \\
(\mathrm{kg} / \mathrm{mol})^{*}\end{array}$ & - & 11 & 11 & 15 & 17 & 17 & 17 & 22 & 23 \\
\hline & $\begin{array}{c}\mathrm{M}_{\mathrm{n} ; \exp } \\
(\mathrm{kg} / \mathrm{mol}) \\
(\mathrm{SEC})\end{array}$ & - & 196 & 251 & 181 & 386 & 214 & 583 & 239 & 196 \\
\hline & $\bigoplus$ & - & 4.69 & 3.47 & 4.74 & 2.41 & 2.59 & 1.78 & 2.14 & 2.42 \\
\hline \multirow{4}{*}{$\begin{array}{l}\text { Polymerization in } \\
\text { miniemulsion } \\
10 \mathrm{w}-\%\end{array}$} & $\begin{array}{c}\mathrm{M}_{\mathrm{n} ; \mathrm{th}} \\
(\mathrm{kg} / \mathrm{mol})^{*}\end{array}$ & - & - & - & - & 2.4 & 4.1 & 5.5 & 8.6 & 10.1 \\
\hline & $\begin{array}{c}\mathrm{M}_{\mathrm{n} ; \exp } \\
(\mathrm{kg} / \mathrm{mol}) \\
(\mathrm{SEC})\end{array}$ & - & - & - & - & 486 & 203 & \multicolumn{3}{|c|}{$\begin{array}{l}\text { Not soluble } \\
\text { in THF }\end{array}$} \\
\hline & $\oplus$ & - & - & - & - & 3.43 & 8.9 & & & \\
\hline & $\begin{array}{l}\text { Average } \\
\text { diameter } \\
(\mathrm{nm})(\mathrm{DLS})\end{array}$ & 82 & - & - & - & 79 & 88 & 88 & 104 & 105 \\
\hline
\end{tabular}

* $M_{n ; t h}=\pi_{N b} x M_{N b} x n_{N b} /\left(n_{[R u C l 2(p C y)] 2} / 2\right)$ where $\pi_{N b}$ is the Nb conversion, $M_{N b}$ is the molecular weight of $N b, n_{N b}$ is the initial amount of $\mathrm{Nb}, \mathrm{n}_{[\mathrm{RuCl}(\mathrm{pCy})] 2}$ is the initial amount of $\left[\mathrm{RuCl}_{2}(\mathrm{pCy})\right]_{2}$ 


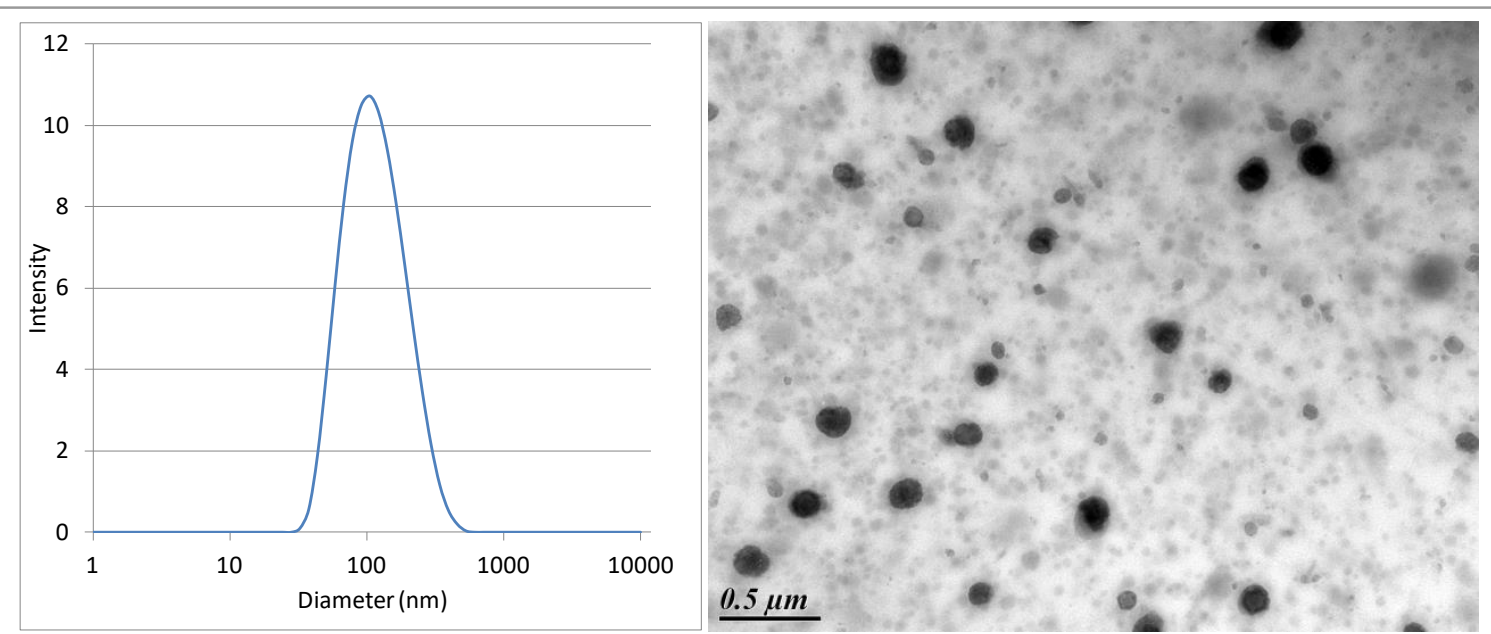

Figure 4: Particle size distribution (Intensity (\%)) of the PNb latex obtained after ROMP in miniemulsion at $10 \mathrm{w}$-\% and TEM picture of the final particles.

Polymerization with $\left[\mathrm{RuI}_{2}(\mathrm{pCy})\right]_{2}$ as ruthenium pre-catalyst: As shown in previous section, $\left[\mathrm{RuCl}_{2}(\mathrm{pCy})\right]_{2}$ alone can catalyze without NHC the ROMP of $\mathrm{Nb}$ in solution and in miniemulsion, leading to a competitive initiation mechanism. To overcome this issue, $\left[\mathrm{RuI}_{2}(\mathrm{pCy})\right]_{2}$ was proposed as a good candidate to gain complete photolatency in absence of NHC. Indeed, changing the chloride ligands by iodide ligands could induce latency of this system because of an increase of the steric hindrance and thus a limited coordination of Nb. ${ }^{34}$ Figure 5 (blue and green curves) displays the $\mathrm{Nb}$ conversion versus the irradiation time for the $\mathrm{NHC}$ precursor system IMesH ${ }^{+} \mathrm{BPh}_{4}^{-} /$ITX together with the precatalyst $\left[\mathrm{RuI}_{2}(\mathrm{pCy})\right]_{2}$. In solution (Figure 5 , blue curve), this tricomponent system allowed monomer conversion to reach only $45 \%$ after 30 minutes of irradiation, revealing a less active catalytic system for ROMP of $\mathrm{Nb}$ than the tricomponent system employing $\left[\mathrm{RuCl}_{2}(\mathrm{pCy})\right]_{2}$. Nevertheless, in sharp contrast with $\left[\mathrm{RuCl}_{2}(\mathrm{pCy})\right]_{2}$, no $\mathrm{Nb}$ conversion was observed when $\left[\mathrm{RuI}_{2}(\mathrm{pCy})\right]_{2}$ ruthenium complex was used alone (red curve, Figure 5). Thus, the combination of $\mathrm{IMesH}^{+} \mathrm{BPh}_{4}-/ \mathrm{ITX}$ with $\left[\mathrm{RuI}_{2}(\mathrm{pCy})\right]_{2}$ provides a fully photolatent system for the ROMP of $\mathrm{Nb}$, with no competitive initiation mechanism.

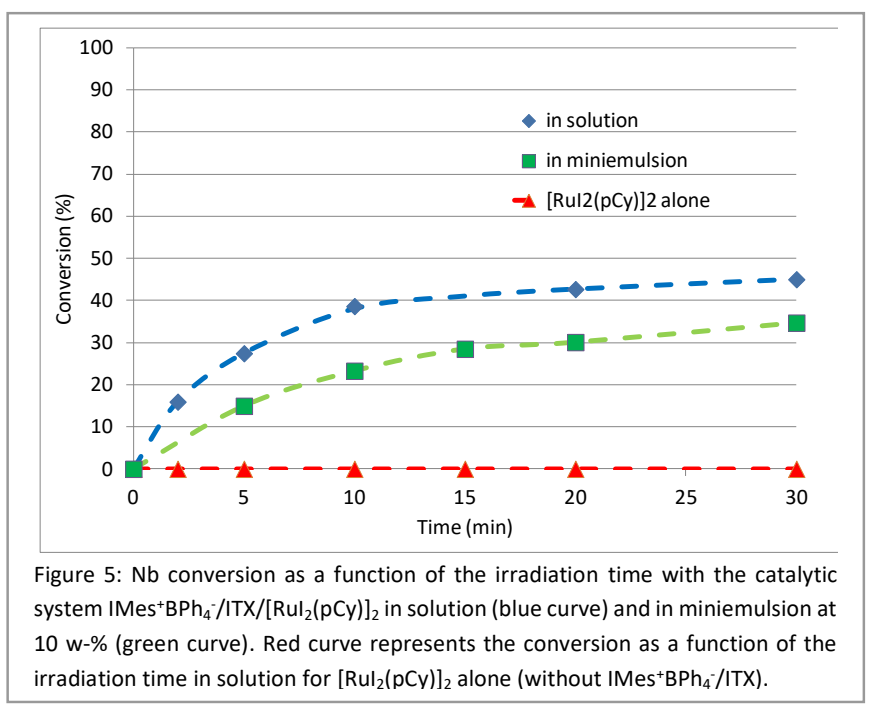

Regarding the ROMP in miniemulsion at $10 \mathrm{w} / \mathrm{w}-\%$ with this new catalytic system $\mathrm{IMesH}^{+} \mathrm{BPh}_{4}-/ \mathrm{ITX} /\left[\mathrm{RuI}_{2}(\mathrm{pCy})\right]_{2}$, polymers were obtained with slightly lower conversion $(30 \%$ after 30 minutes of irradiation) than in solution. Good colloidal stability of the final dispersion could also be noted with particle sizes ( $D$ $=74 \mathrm{~nm}(0.49))$ close to the initial droplet size $(D=83 \mathrm{~nm}(0.32))$.

\section{Conclusions}

In this contribution, Nb ROMP in miniemulsion was performed through a new photo-latent catalytic system. First, the miniemulsion formulation was optimized in order to obtain aqueous $\mathrm{Nb}$ miniemulsions with initial droplets smaller than $100 \mathrm{~nm}$. Droplets with diameter of $36 \mathrm{~nm}(\mathrm{PDI}=0.271)$ and 64 $\mathrm{nm}(\mathrm{PDI}=0.228)$ for miniemulsion at $5 \mathrm{w} / \mathrm{w}-\%$ and $10 \mathrm{w} / \mathrm{w}-\%$ respectively were obtained. The UV attenuation of these emulsions was checked by UV-visible spectroscopy.

Then, polymerizations were carried out by adding in the organic phase IMesH ${ }^{+} \mathrm{BPh}_{4}^{-}, \mathrm{ITX}$ and $\left[\mathrm{RuCl}_{2}(\mathrm{pCy})\right]_{2}$, in order to generate in situ a Noels' catalyst type complex in the droplets. Thanks to this new initiator, PNb were obtained by ROMP of $\mathrm{Nb}$ in solution and in miniemulsion with conversions up to $98 \%$ and $55 \%$ respectively. Despite these encouraging results, $\left[\mathrm{RuCl}_{2}(\mathrm{pCy})\right]_{2}$ alone appears to initiate the ROMP of Nb under UV irradiation, giving rise to a competition between two initiation mechanisms. In order to overcome this drawback, its iodine homologue $\left[\mathrm{RuI}_{2}(\mathrm{pCy})\right]_{2}$ was used and proved to be fully inactive alone for the ROMP of $\mathrm{Nb}$ under UV irradiation (fully latent system), while in the presence of $\mathrm{IMesH}^{+} \mathrm{BPh}_{4}{ }^{-}$and ITX it allowed reaching $\mathrm{Nb}$ conversions of about $50 \%$ in solution and about $35 \%$ in miniemulsion at $10 \mathrm{w} / \mathrm{w}-\%$ of dispersed phase.

In this first study, we thus demonstrated the potential of photolatent catalytic systems to obtain PNb by ROMP in aqueous miniemulsion. In a future work, use of another irradiation system, composed of a LED lamp and an annular reactor will be explored with this photoROMP system, with the aim to scale-up the production of PNb particles. Particular attention will be paid to the influence of the reactor geometry and the lamp power on the reactions efficiencies. 


\section{Acknowledgements}

Authors would like to thanks the French "Agence Nationale pour la Recherche" for the financial support (ANR program: DS0304 2016, contract number: ANR-16-CE07-0016). The microscopy was carried out in the Bordeaux Imaging Center, a service unit of the CNRS-INSERM and Bordeaux University, member of the national infrastructure France Biolmaging.

\section{References}

1 A.M. Van Herk, Chemistry and Technology of Emulsion Polymerization. Wiley-VCH: Weinheim, 2013, ISBN: 978-1119-95372-2.

2 J.M. Asua, Special Issue on Polymer Chemistry, 2014, 39, 1797.

3 J.M. Asua, Progress in Polymer Science, 2002, 27, 1283.

4 K. Landfester, and D. Crespy, Miniemulsion Polymerization. In Materials Science and Technology. R. W. Cahn, P. Haasen and E. J. Kramer, 2013, 449.

5 C.K. Weiss and K. Landfester, Miniemulsion Polymerization as a Means to Encapsulate Organic and Inorganic Materials. In Hybrid Latex Particles. Advances in Polymer Science, vol 233. Springer, Berlin, Heidelberg, 2010.

6 J.P. Claverie, S. Viala, V. Maurel and C. Novat, Macromolecules, 2001, 34, 382.

7 D. Quémener, V. Héroguez and Y. Gnanou, Journal of Polymer Science part A: Polymer Chemistry, 2006, 44, 2784.

8 D. Quémener, A. Bousquet, V. Héroguez and Y. Gnanou, Macromolecules, 2006, 39, 5589.

9 C. Airaud, V. Héroguez and Y. Gnanou, Macromolecules, 2008, 41, 3015.

10 D. Le, V. Montembault, S. Pascual, F. Collette, V. Héroguez and L. Fontaine, Polymer Chemistry, 2013, 4, 2168.

11 S. Monsaert, N. Ledoux, R. Drozdzak and F. Verpoort, Journal of Polymer Science part A: Polymer Chemistry, 2010, 48, 302.

12 N. Kohut-Svelko, R. Pirri, J.M. Asua and J.R. Leiza, Journal of Polymer Science part A: Polymer Chemistry, 2009, 47, 2917.

13 X. Gstein, D. Burtscher, A. Szadkowska, M. Barbasiewicz, F. Stelzer, K. Grela and C. Slugovc, Journal of Polymer Science part A: Polymer Chemistry, 2007, 45, 3494.

14 A. Piermattei, S. Karthikeyan and R.P. Sijbesma, Nature Chemistry, 2009, 1, 133.

15 R.S. Stoll and S. Hecht, Angewandte Chemie International Edition, 2010, 49, 5054.

16 F. Jasinski, P.B. Zetterlund, A.M. Braun and A. Chemtob, Progress in Polymer Science, 2018, 84, 47.

17 K. Jung, J. Xu, P.B. Zetterlund and C. Boyer, ACS Macro Letters, 2015, 4, 1139.

18 R.A. Weitekamp, H.A. Atwater and R.H. Grubbs, Journal of the American Chemical Society, 2013, 135, 16817.

19 D. Wang, J. Unold, M. Bubrin, I. Elser, W. Kaim, G. Xu and M. Buchmeiser, European Journal of Inorganic Chemistry, 2013, 2013, 5462.

20 A. Ben-Asuly, A. Aharoni, C. Diesendruck, Y. Vidavsky, I. Goldberg, F.B. Straub and N.G. Lemcoff, Organometallics, 2009, 28, 4652.

21 E. Levin, S. Mavila, O. Eivgi, E. Tzur and N.G. Lemcoff, Angewandte Chemie International Edition, 2015, 54, 12384.

22 R.L. Sutar, E. Levin, D. Butilkov, I. Goldberg, O. Reany and N.G. Lemcoff, Angewandte Chemie International Edition, 2016, 55, 764.

23 A.J. Teator, H. Shao, G. Lu, P. Liu and C.W. Bielawski, Organometallics, 2017, 36, 490.

24 V. Sashuk and O. Danylyuk, Chemistry a European Journal, 2016, 22, 6528.

25 J. Pinaud, T.K.H. Trinh, D. Sauvanier, E. Placet, S. Songsee, P. Lacroix-Desmazes, J.M. Becht, B. Tarablsi, J. Lalevée, L.
Pichavant, V. Héroguez and A. Chemtob, Chemistry $a$ European Journal, 2018, 24, 337.

26 " Carbènes N-hétérocycliques photolatents et compositions photo-polymérisables "J. Pinaud, A. Chemtob, V. Héroguez, Patent FR1656744; 08/2015

27 L. Delaude and A. Demonceau, Dalton Transactions, 2012, 41, 9257.

28 L. Delaude, A. Demonceau and A.F. Noels, Chemical Communications, 2001, 0, 986.

29 E. Lobry, F. Jasinski, M. Penconi, A. Chemtob, C. Ley, C. Croutxé-Barghorn, E. Oliveros, A.M. Braun and A. Criqui, Macromolecular Chemistry and Physics, 2014, 215, 1201.

30 E. Alcalde, I. Dinares, A. Ibanez and N.A. Mesquida, Chemical Communications, 2011, 47, 3266.

31 R. Marcilla, J. Alberto-Blazquez, J. Rodriguez, J.A. Pomposo and D. Mecerreyes, Journal of Polymer Science part A: Polymer Chemistry, 2003, 42, 208.

32 O. Behrend, K. Ax and H. Schubert, Ultrasonics Sonochemistry, 2000, 7, 77.

33 X. Sun, J.P. Gao and Z.Y. Wang, Journal of the American Chemical Society, 2008, 130, 8130.

34 R.M. Thomas, A. Fedorov, B.K. Keitz and R.H. Grubbs, Organometallics, 2011, 30, 6713. 